\title{
The Development of Self-Knowledge in Plato's Philosophy
}

\section{El desarrollo del autoconocimiento en la filosofía de Platón}

\author{
Manuel C. ORTIZ dE LANDAZURI \\ (Universidad de Navarra)
}

Recibido: 11/09/2014

Aceptado: 12/11/2014

\begin{abstract}
The aim of this paper is to examine how the Greek motto $\gamma \nu \tilde{\omega} \theta \imath \sigma \varepsilon \alpha v \tau$ ó $v$ plays a central role in Plato's philosophy in order to show how ethics and knowledge go hand in hand in his model of $\pi \alpha 1 \delta \varepsilon i ́ \alpha$. The question of self-knowledge is a practical and theoretical task in life which is developed implicitly in his dialogues, it is for this reason that I examine some passages of the Charmides, Alcibiades I, Phaedo and Republic in order to show how Plato discovers the human interiority (Phaedo) and how self-knowledge is refined and articulated with the tripartition of the soul in the Republic.
\end{abstract}

Keywords: Awareness, Interiority, Purification, Soul.

Although Greek thinkers didn't develop a clear concept of self-knowledge, this question is present in theoretical and practical topics of the Greek tradition. Plato's philosophy can be explained as a process of self-knowledge and purification, and in this paper I will try to show the way in which Platonic philosophy is a development

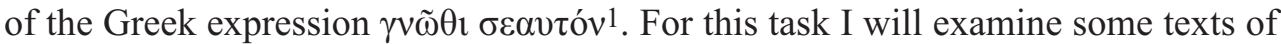
the Charmides, Alcibiades I, Phaedo and Republic in order to explain that the ques-

\footnotetext{
1 The question of self-knowledge in Plato has been studied mostly attending to the early dialogues. The aim of this paper is to show that self-knowledge is a topic which is presented and developed in different ways in other dialogues. For the question of self-knowledge in the early dialogues see Annas, J.: "Self-Knowledge in Early Plato", Platonic Investigations, D. J. O'Meara (ed.), Catholic University of America Press, Washington, 1985, pp. 111-138.
} 
tion of self-knowledge is a central topic in his philosophy which is refined with the development of his own metaphysics and psychology2. The aim of this paper is not to see how Plato speaks of self-awareness or self-perception ${ }^{3}$, but rather to show the role that self-reflection plays in his philosophy. As I will try to explain, Plato's theory of recollection of the Phaedo and the way of contemplation of the Good in the Republic are answers to the problem of self-knowledge and the relation of virtue and knowledge.

\section{Self-knowledge as a practical task in life: Charmides, Alcibiades I}

In the Charmides Plato tries to clarify the concept of $\sigma \omega \varphi \rho \circ \sigma u ́ v \eta$ and the meaning of the Delphic expression: $\gamma v \tilde{\omega} \theta t \sigma \varepsilon \alpha v \tau o ́ v$. The word $\sigma \omega \varphi \rho о \sigma u ́ v \eta$ doesn't have a direct translation into modern languages, because the concept expressed in Greek is very rich in content: self-moderation, prudence, good judgement, excellence of the soul ${ }^{4} . \Sigma \omega \varphi \rho о \sigma v ́ v \eta$ is understood in this dialogue in terms of self-moderation and inner order, and the connection that Critias establishes with self-knowledge is especially interesting to examine:

I'd almost be prepared to say that knowing oneself ( what self-control is. I agree with whoever it was who dedicated the inscription to that effect at Delphi, and I think it was set up as an alternative greeting from the god to those entering his shrine instead of "Be well and happy". It's as if saying "Be well and happy" isn't an appropriate form of greeting -as if it's more important to recommend self-control to one another than that- and so the god doesn't greet those who enter his shrine with the form of address we normally use. This, I think, was the intention of the man who dedicated the inscription: essentially, he's claiming that what the god is saying to anyone who enters the shrine is "Be self-controlled". Like a professional diviner, how-

\footnotetext{
2 In this sense I don't see a big contrast between the early and middle dialogues. From my point of view we find more refined anwers to the same problems. Penner and Rowe have pointed out a high contrast between Socrates' moral intellectualism and the Platonic position. See Penner, T.-Rowe, C. J.: “The Desire for Good: Is the Meno Inconsistent with the Gorgias?", Phronesis 39 (1994), p. 18. This contrast is not well justified since they study the figure of Socrates from Gorgias and Meno, two dialogues that are not far from Republic.

3 Self-awareness and self-perception are psychological modern terms related to the capacity of the human being to be aware of himself. In this paper I prefer to speak of self-knowledge as a broad term related with self-reflection as a practical and theoretical attitude. See Napolitano, L. M.: "Plato and the Problem of Self-Awareness", Inner Life and Soul. Psyche in Plato, M. Migliori, L. M. Napolitano, A. Fermani (eds.), Academia, Sankt Agustin, 2011, pp. 151-184.

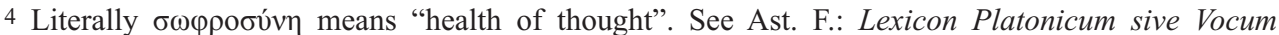
Platonicarum Index, vol. III, Libraria Weidmanniana, Leizpig, 1838 (repr. Cambridge University Press, 2012) p. 354; Pinilla, A.: Sofrosine. Ciencia de la ciencia, Consejo Superior de Investigaciones Científicas, Madrid, 1959, pp. 23-25.
} 


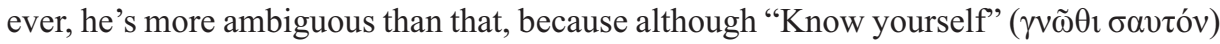
and "Be self-controlled" ( $\sigma \omega \varphi \rho o ́ v \varepsilon \imath)$ are the same (as the inscription claims, with my agreement), they might be taken to be different (Charmides $164 \mathrm{~d}-165 \mathrm{a})^{5}$.

Critias is sure that the real meaning of $\sigma \omega \varphi \rho \circ \sigma u ́ v \eta$, which is what Socrates and his friend are looking for in the dialogue, is an ethical imperative ("be self-controlled") which consists in acting in a rational and moderate way. In this dialogue, however, a new element appears in the concept of $\sigma \omega \varphi \rho о \sigma u ́ v \eta$, because it is not only understood in terms of moderation or excellence in actions, but also as a reflexive movement of the subject towards himself: to be self-controlled is to know yourself, and one possesses $\sigma \omega \varphi \rho \circ \sigma u ́ v \eta$ inasmuch as he knows what he is really doing with his life. It is necessary to clarify that this concept of self-knowledge doesn't have for Plato a meaning of direct knowledge of the subject towards himself: he is not referring to an activity of self-consciousness, as modern thinkers speak of self-knowledge 6 , but it is an awareness of the real value of one's own actions ${ }^{7}$. Temperance ( $\left.\sigma \omega \varphi \rho \circ \sigma u ́ v \eta\right)$ is a knowledge of oneself because it is precisely the acknowledgement of the proper limits: «This is what it is to be self-controlled, what self-control is, and what knowing oneself is: it is knowing what one knows and what one doesn't know ( (Charmides, 167 a).

Self-knowledge is related with the acknowledgement of the limits of one's

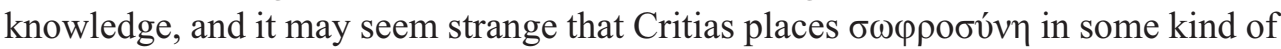
epistemological field. It may be noticed, however, that Plato doesn't use a clear concept of $\dot{\varepsilon} \pi \imath \tau \eta \dot{\mu} \mu \eta$ and $\tau \dot{\varepsilon} \chi \nu \eta^{8}$ and, at least in the early dialogues, the main question

\footnotetext{
5 For the Charmides I use R. Waterfield's translation (Meno and Other Dialogues: Charmides, Laches, Lysis, Meno, Oxford University Press, Oxford, 2005).

6 See Oehler, K.: Subjektivität und Selbstbewußtsein in der Antike, Königshausen \& Neumann, Würzburg, 1997, pp. 24-25.

7 "Gerade der Zusammenhang, der zwischen den resten beiden Definitionsversuchen des Charmides und der Bestimmung des Sich-Selbst-Kennens besteht, macht den Abstand sichtbar, der die Sophrosyne als Fähigkeit, sich selbst Andere sein zu können, von dem modernen Begriff der Selbsterkenntnis. Nicht ein Erforschthaben des eigenen Herzens, eine Kenntnis der geheimen Motive des eigenen Handelns ist mit der griechischen Forderung des Sich-Selbst-Kennens gemeint, sondern die Fähigkeit, dieses Handeln selbst (auf Motive und Triebfedern ist dabei gar nicht reflektiert) aus der Warte anderer sehen zu können. Nicht im Blick eines allwissenden Gottes, sondern mit den Augen der Andern soll ich auf mich sehen können. Nicht die Gründe, sondern die Grenzen seines Handelns zu kennen, ist es, was des Besonnenen auszeichnet". Ebert, T.: Meinung und Wissen in der Philosophie Platons, Walter de Gruyter, Berlin/New York, 1974, p. 58.

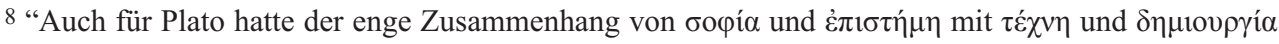
tiefere Bedeutung; seine Anschauung vom Wissen des Handwerkers ist gewissermaßen das noch unverarbeitete Material für sein philosophisches Denken. Im Handwerker verkörpert sich für ihn der Begriff $\dot{\varepsilon} \pi \iota \tau \eta \dot{\mu} \eta$ mit der in ihm liegenden Problematik, die darin besteht, dass das Wort auf der einen Seite die Gewissheit, auf der anderen Seite die Richtung auf ein Ziel forderte. Und diese beiden Seiten
} 
is in which sense there is knowledge in virtue. One the one hand if virtue was a $\tau \varepsilon \dot{\varepsilon} \chi \eta$ (practical skill), then it would produce something, but, on the contrary, that is not what happens: virtue is not a productive skill. On the other hand if virtue was $\dot{\varepsilon} \pi \iota \tau \eta \dot{\mu \eta}$ (theoretical knowledge) it should have a particular object of study, but this is not the case 9 . A virtuous person is not an expert of something in particular, and he doesn't know too much about something. A virtuous person is just someone who

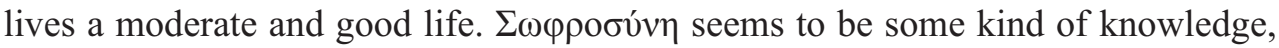
but not of exterior objects, but of the inner life: self-knowledge consists -as Critias says- in acknowledgement of one's ignorance and wisdom.

On the other hand it is interesting to consider that in the Greek tradition a wise man is not only one who has knowledge, but one who lives in accordance with that knowledge. Wisdom has a theoretical and practical aspect ${ }^{10}$. Plato links $\sigma \omega \varphi \rho \circ \sigma u ́ v \eta$ in this dialogue with some kind of theoretical and practical knowledge which allows someone to acknowledge his own limits:

Only a self-controlled man, then, will know himself and will be capable of looking to see what he actually knows and what he doesn't know. By the same token only a selfcontrolled man will be capable of examining others to see what a person knows and thinks he knows (assuming that he does have knowledge), and whether there are things which he thinks he knows, but doesn't really. And no one else will be capable of doing this (Charmides, 167 a).

A self-controlled man has introduced an inner order which allows him to acknowledge his own limits and to examine other person's knowledge. In this sense $\sigma \omega \varphi \rho о \sigma u ́ v \eta$ is a rational disposition of self-control necessary to have a real knowledge. How is this possible? Why is it necessary to live according to reason (virtue) in order to have a real knowledge of oneself? This practical-theoretical connection is clearer in the Republic, where Plato establishes the tripartition of the soul, but in the Charmides he doesn't seem to give a clear answer. This relation between wisdom and acknowledgement of ignorance, nonetheless, has a strong connection with some passages of the Apology which can give shed some light on understanding Plato's conception of wisdom ( бофí $\alpha$ ) and self-knowledge in the earlier dialogues:

But, gentlemen of Athens, it seemed to me that the poets and our capable public craftsmen had exactly the same failing ( $\dot{\alpha} \mu \alpha \dot{\rho} \rho \tau \eta \alpha)$ ) because they practiced their own arts

schienen sich auszuschließen: der Handwerker mochte Sicherheit besitzen, dafür blieb er auf sein Spezialfach beschränkt; dem, der vorgab, eine weitere Weisheit zu besitzen, war leicht zu beweisen, dass er nichts wusste". Snell, B.: Die Ausdrücke für den Begriff des Wissenschaft in der vorplatonischen Philosophie, Weidmannsche Buchhandlung, Berlin, 1924, pp. 12-14.

9 See Meno, $99 \mathrm{c}$.

10 See Hadot, P.: "La figure du sage", Études de philosophie ancienne, Les belles lettres, Paris, 1998, pp. 233-254. 


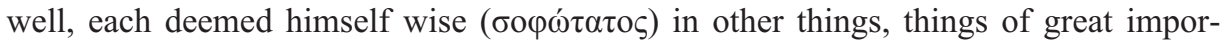
tance. This mistake quite obscured their wisdom ( was that I asked myself ( $\dot{\varepsilon} \mu \alpha v \tau o ̀ v \dot{\alpha} v \varepsilon \rho \omega \tau \tilde{\alpha} v)$ on behalf of the oracle whether I would accept being such as I am, neither wise with their wisdom nor foolish with their folly, or whether I would accept then wisdom and folly together and become such as they are. I answered, both for myself and the oracle, that it was better to be as I am (Apology, 22 d-e) $)^{11}$.

It is through an exercise of recollection and self-examination that Socrates acknowledges his ignorance and decides to live with moderation, without pretending to be what he is not. The connection of this passage with the Charmides points out that self-knowledge as $\sigma \omega \varphi \rho о \sigma u ́ v \eta$ is a practical task in life which consists of

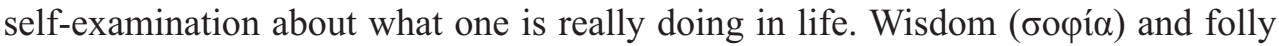
$(\dot{\alpha} \mu \alpha \theta i \alpha)$ are not theoretically acquired dispositions, but rather a practical attitude towards one's own limits. In the wise man there is no disharmony between what he really is and what he thinks he is. The problem of craftsmen and politicians is that they think they know everything when they really don't know anything.

Socrates' statement of his own ignorance in the Apology points to a level of knowledge which is previous and deeper than that of the sciences and crafts. Socrates doesn't have any science or craft, but he is able to acknowledge his own ignorance, and this self-disposition makes him wiser than anyone else ${ }^{12}$, because people who have science or skills think they know, but they don't really know anything. Socrates at least is aware of the limits of his knowledge, and he realizes

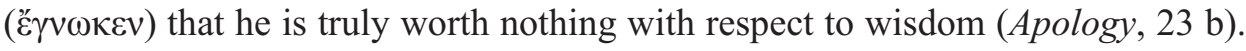

Turning back to the Charmides, it is then surprising that the identification of

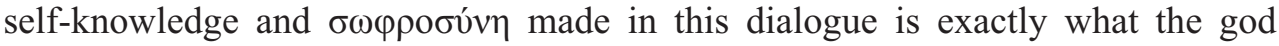
assigns to Socrates in the Apology. There is no one wiser than Socrates because he is the only one who acknowledges his own ignorance; this kind of knowledge is precisely the $\sigma \omega \varphi \rho о \sigma u ́ v \eta$ and the proper meaning of the expression $\gamma \nu \tilde{\omega} \theta \imath$ $\sigma \varepsilon \alpha v \tau o ́ v$. Socrates is the man who fulfils the commandment and greeting of the god.

But Plato in the Charmides tries to go further. Critias has said that $\sigma \omega \varphi \rho \circ \sigma u ́ v \eta$ is self-moderation and self-knowledge, and suggests that perhaps this is a knowledge of good and evil, and Socrates replies:

You've been leading me astray all this time! You've been concealing the fact that it isn't living in conformity with knowledge that causes us to thrive and be happy -or at least

11 For the Apology I use R. E. Allen's translation (Yale University Press, New Haven and London, 1984) with some little variations.

12 See Napolitano, L. M.: "Plato and the Problem of Self-Awareness", Inner Life and Soul. Psyche in Plato, M. Migliori, L. M. Napolitano, A. Fermani (eds.), Academia, Sankt Agustin, 2011, p. 168. 
that it isn't the possession of all the other branches of knowledge, but just this one branch, which is concerned with good and bad (Charmides, $174 \mathrm{a}$ ).

The acknowledgment of one's own limits (one's ignorance and wisdom) is identified at the end with a peculiar science of good and evil. Why? Because evil consists in thinking that one is more than what one really is. Bad actions spring from this foolish disposition ( $\dot{\alpha} \mu \alpha \theta i ́ \alpha)$. Self-knowledge in the Charmides is a practical inner order which consists acknowledging the limits, and this is a science of good

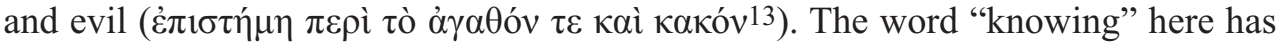
more to do with the practical than with a theoretical disposition: one knows himself when he lives rationally, when he introduces in his own life a rational order (moderation), and this is only possible when one acknowledges his own limits.

Nevertheless, up to this point, Socrates and Critias are not able to conclude in

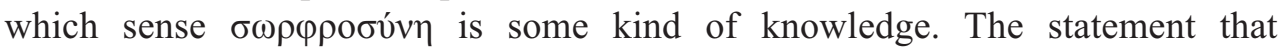

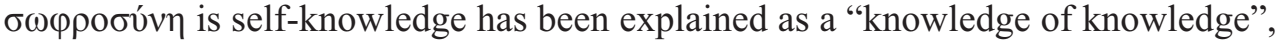
and then as "knowledge of good and evil". The problem is that it is not a theoretical knowledge about other sciences, but a practical-reflexive knowledge 14 that Plato is not able to clarify ${ }^{15}$. As it happens in many other dialogues of Plato, the topic remains unanswered 16 . Critias and Socrates have presented several visions of the $\sigma \omega \varphi \rho о \sigma u ́ v \eta$ without reaching a clear definition. It seems interesting to emphasise, however, that Plato has explored the connection between self-knowledge and ethi-

13 In this sense there seems to be a strong connection between Charmides and the Republic, where the highest knowledge and science is the contemplation of Goodness. See Adamietz, J.: "Zur Erklärung des Hauptteils von Platons Charmides", Hermes 97 (1969), pp. 55-57. It is also interesting the connection that Huber establishes between $\alpha$ 'ó $\mu v \eta \sigma ı \varsigma$ (Phaedo) and self-knowledge (Charmides): the notion of òvó $\mu \nu \eta \sigma ı \varsigma$ could be understood as a development of that "knowledge of knowledge". See Huber, C. E.: Anamnesis bei Plato, Max Hueber, München, 1964, p. 543.

14 "The Charmides thus implies that knowledge of the good is different in kind from technai such as those of medicine and navigation. We all want the good and think we know what sorts of thing are good, but our judgement is generally distorted by our appetites and desires. To know the good is to know what we ourselves really want. This self-knowledge is achieved not by conventional instruction but through self-examination". Stalley, R. F.: "Sophrosune in the Charmides", Plato. Euthidemus, Lysis, Charmides. Proceedings of the V Symposium Platonicum, T. M. Robinson y L. Brisson (eds.), Academia Verlag, Sankt Agustin, 2000, p. 276.

15 McKim suggests that Plato could be trying to show the limitations of the Socratic method. Socrates wouldn't be able to explain his own virtue (that is, the declaration of ignorance: whe only knows that he doesn't know), and in this sense the Charmides could be seen as a point of distance towards his master. See McKim, R.: "Socratic Self-Knowledge and «Knowledge of Knowledge» in Plato's Charmides", Transactions of the American Philological Association 115 (1985), p. 60.

16 It is not easy to explain how Plato changes the discussion of the dialogue from self-knowledge to "knowledge of knowledge" and if there is a connection between self-knowledge and knowledge of knowledge or they are different questions. See Annas, J.: "Self-Knowledge in Early Plato", Platonic Investigations, D. J. O’Meara (ed.), Catholic University of America Press, 1985, pp. 134-135. 
cal virtue, and it can be stated that it is only possible to reach a virtuous life in the way someone introduces rational order, and this rational order is only possible if someone knows the real value of his actions. The rational and reflexive task of selfknowledge is a necessary condition to reach virtue. But, on the other hand, I would like to point out that the connection between self-knowledge and virtue implies also a necessary good behaviour in order to get to know oneself 17 . Although this idea is not explicitly said in Charmides, it is something that appears implicitly in Plato's Phaedo and Republic.

Which kind of self-knowledge do we find in Plato's Charmides? It is neither a science of the objects of the world, nor a practical skill, but a deeper level of knowledge: is to be aware of one's reality and the real value of one's actions and knowledge. This is only possible in the way we examine our own actions ${ }^{18}$. We know ourselves when we "realize" what we are really doing: this reveals an indirect selfknowledge structure in which the subject knows himself insofar he knows better his relation with the world 19 .

The problem of self-knowldege appears also in Alcibiades I, where Socrates and Alcibiades discuss the kind of knowledge a good politician must have in order to rule the city ${ }^{20}$. A good politician doesn't need to have knowledge of practical skills (107 b), but rather must be able to know what is just ( lem arises when they ask themselves what is that kind of knowledge: it seems that one knows what is just and unjust from early childhood (110 b). Alcibiades doesn't know how is this possible and replies that the politician doesn't have to discuss

17 It has been object of recent discussion in which way is Socrates position intellectualistic. Brickhouse and Smith argue that Socrates defended a motivational intellectualism and when we choose to do something we are supposing (cognitive element) that there is a good for ourselves in that election. In this way they defend that even though Socrates says that virtue is knowledge there are also desiderative and appetitive elements that need control in order to achieve virtue. See Brickhouse, T. C.,-Smith, N.: Socratic Moral Psychology, University Press, Cambridge, 2010. The same line of interpretation we find in Segvic, H., "No One Errs Willingly: The Meaning of Socratic Intellectualism", Oxford Studies in Ancient Philosophy 19 (2000), pp. 1-45. Socrates' moral intellectualism has been put into context and explained by Nehamas, A.: "Socratic Intellectualism", Virtues of Authenticity: Essays on Plato and Socrates, University Press, Princeton, 1999, pp. 27-58.

18 In this sense Plato's account of $\sigma \omega \varphi \rho \sigma^{\prime} v \eta$ is a shift in respect to the sophists: they praised selfmoderation because it could be useful and bring benefits. See Lodge, R. C.: Plato's Theory of Ethics, Kegan Paul, New York, 1928, pp. 412-413.

19 See Wieland, W.: Platon und die Formen des Wissens, Vandenhoeck \& Ruprecht, Göttingen, 1999, p. 313.

20 There is no treatment in Plato of self-awareness or self-consciousness, which are topics of Modern philosophy. Plato is trying to answer what is the most noble and essential part of the human being. The

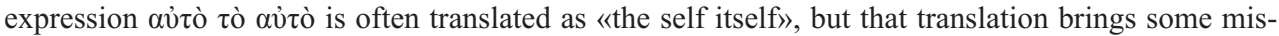
leading connotations. As Gill suggests, it can be better to translate the expression as «itself itself» or, to say with other words, «what we ourselves are» See. Gill, C.: The Structured Self in Hellenistic and Roman Thought, Oxford University Press, Oxford, 2006, p. 351. 
about what is just, being evident, but try to know what is convenient ( $\tau$ ò $\sigma \cup \mu \varphi \varepsilon ́ p o v \tau \alpha, 113 \mathrm{~d})$. Then Socrates states that the problem remains unsolved: one is not able to say if one has learned by oneself what is convenient or whether it has been learned from someone else. Nevertheless, it accords with each other that what

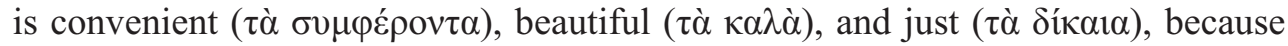
just actions are beautiful and convenient (116 c-d). Up to his point Alcibiades' confusion reaches its highest point, and he recognizes his own ignorance about the question (118 b, $127 \mathrm{~d})$. How could he rule the city when he ignores the most simple notions of justice?

The question can only be solved trying to understand what is «to take care over oneself» ( doesn't help to make any of our possesions better, but rather looks for our own good, helps to make ourselves better (128 d-e). Socrates is refering to a kind of knowledge, different from the other arts, that looks for the good of the human being as a whole. Other arts and sciences aim at a particular good (clothes, shoes, food, health, etc.), but this kind of knowledge pursues the good of the human being in all his dimensions. In other dialogues, it is also called "kingly art" ( $\beta \alpha \sigma 1 \lambda \imath \kappa \eta \dot{~} \tau \varepsilon \dot{\chi} \chi \eta \eta$

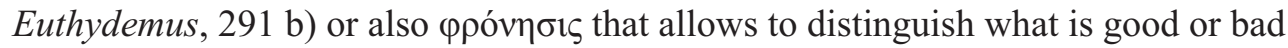
in order to be happy (Meno, $88 \mathrm{c}-\mathrm{d}$ ). This kind of knowledge, necessary to get virtue, is only possible when we try to know ourselves: "If we have that knowledge, we are likely to know what pains to take over ourselves; but if we have it not, we never can» (129 a). Socrates and Alcibiades have reached the main question: what is really the human being? It is not his body, but his soul, that rules the body: «Then he who enjoins a knowledge of oneself bids us become acquainted with the soul» $(130 \text { e })^{21}$. The soul, however, can only know itself when she looks into her most noble part:

If the soul too, my dear Alcibiades, is to know itself, she must surely look at a soul, and especially at that region of it in which occurs the virtue of a soul: wisdom, and at any other part of a soul which resembles this (133 b).

Self-knowledge turns out to be in this dialogue an inquiry towards the most divine part of the soul (133 c), but, in any case, it remains unclear at the end which kind of knowledge is this and how is this possible. Nevertheless, in Alcibiades I and Charmides we find the grounds to solve the problem of self-knowledge and the knowledge of virtue. If Plato doesn't give a clear answer at least he has achieved a possible way to solve it: self-knowledge has to do with a practical disposition in the soul grounded on the contemplation of something divine we find in ourselves. What

${ }^{21}$ For the Alcibiades I I use W. R. M. Lamb's translation (Harvard University Press, Cambridge, 1955). 
kind of knowledge is this? Plato will try to show an answer in the Phaedo and the Republic.

\section{Self-knowledge as an exercise of recollection: Phaedo}

Plato's opposition between appearances and reality of ideas is a fundamental point for his vision of man and self-knowledge in the Phaedo. The main question of the dialogue, if there is life after death, goes hand in hand with very interesting topics of Plato's philosophy and, in this sense, this dialogue also deals with the problem of self-knowledge: in his last hours with his friends Socrates tries to examine what we really are and how can we be sure of our destiny and the real value of our actions. Self-knowledge appears as a process of self-understanding 22 that beginns with the recognition of our bodily human condition.

The main problem of discussion in the Phaedo is the immortality of the soul. Socrates tries to show that the soul is something divine that lives with a body.

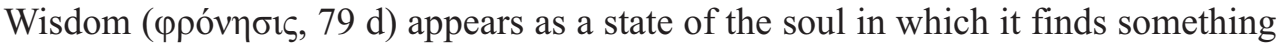
constant and unvarying in a process of self-recollection. The soul reaches his deepest truths looking into itself:

Lovers of knowledge recognize ( $\gamma \iota \gamma v \omega ́ \sigma \kappa o v \sigma \imath)$ that when philosophy takes their soul in hand, it has been bound and glued to the body, and is forced to view the things that are as if through a prison, rather than alone by itself ( $\left.\delta \mathrm{r}^{\prime} \alpha \dot{\tau} \tau \tilde{\eta} \varsigma\right)$; and that is wallowing in utter ignorance $(\dot{\alpha} \mu \alpha \theta i \alpha)$. Now philosophy discerns the cunning of the prison, to examine how it is effected through desire, so that the captive himself may cooperate most of all in his imprisonment (Phaedo, 82 e-83 a) ${ }^{23}$.

Philosophy allows the recognition and self-awareness of our bad condition, it is a process of purification ( $\kappa \alpha \theta \alpha \dot{\rho} \sigma \iota \varsigma)$ in which the subject gets rid of the imprisonment of appearances and understands his own position in the world. Philosophy can be understood as a process of self-recognition towards what is really valuable: when the soul takes notice of the appearances of the world, the soul starts to know something about his real self. In this sense, self-knowledge is a process of self-recognition: the real self is the soul, and the main obstacle to look into ourselves are the bodily appearances, that make the soul look outside of itself. The real philosopher is the one who is able to recognize the real situation of his soul through a process

\footnotetext{
22 It has been often interpreted the theory of recollection as a long process of self-understanding. See Robins, I. N.: "Recollection and Self-Understanding in the Phaedo", Classical Quarterly 47 (1997), pp. 450-451. In the following pages I would like to point out that this process of self-understanding is not only a theoretical exercise, but also a practical and ethical attitude in life.

23 For the Phaedo I use D. Gallop's translation (Clarendon Press, Oxford, 1975).
} 
of self-reflection and purification. For the question of self-knowledge it seems deeply interesting that Plato uses the word $\gamma \iota \gamma \nu \omega ́ \sigma \kappa \varepsilon v^{24}$ referring to the philosophical process of self-clarification. The task of knowing ourselves ( $\gamma \nu \tilde{\omega} \theta \imath \sigma \alpha \nu \tau o ́ v)$ is a process of recognition of our human condition. To know oneself is to recognize

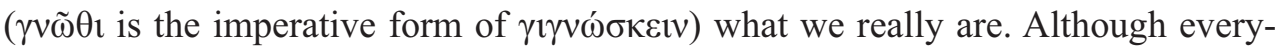
one knows we have a body, only true philosophers recognize ( $\gamma 1 \gamma v \omega ́ \sigma \kappa \varepsilon t v)$ we have a soul that needs recollection. Self-knowldege starts with an inner conversion towards the sensible appearances and a movement of the soul towards itself:

Then doesn't purification turn out to be just what's been mentioned for some while in our discussion, the parting of the soul from the body as far as possible, and the habitu-

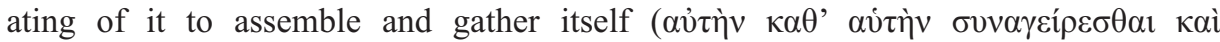

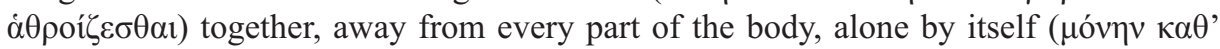
$\alpha \dot{\tau}$ ทेv), and to live, so far as it can, both in the present and in the hereafter, released from the body, as from fetters? (Phaedo, $67 \mathrm{c}-\mathrm{d})$.

The first step in the process of self-knowledge is to remove the obstacles that prevent the soul to look into itself. The most real and inner part of us cannot be aware of itself if the bodily and appetitive desires disturb it the exercise of recollection. The second step is of being alone in recollection, alone by itself, and in this sense the ideal of life proposed by Plato is a process of self-knowledge, not in the sense of self-perception, but as an inner wisdom of what is really valuable for oneself.

It is necessary to reach a state of the soul in which one is able to recognize that the simple perceptions are full of deceit ( $\dot{\alpha} \pi \alpha \dot{\tau} \eta, 83$ a) and it is better for the soul

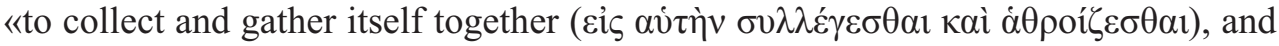
to trust none other but itself, whenever, alone by itself, it thinks of any of the things that are, alone by itself; and not no regard as real what it observes by other means»» (83 a-b). We may think that this is obviously an epistemological exercise in order to get true knowledge, and it is, but I would like to suggest that it is also an ethical process. Through the main sensible knowledge we are not able to appreciate what is really valuable for ourselves, and it seems necessary to know what is really valuable (in the epistemological and ethical field) through a process of self-knowledge. Only when the soul can gather itself it is possible to find true knowledge about our-

\footnotetext{
24 The term $\gamma \mid \gamma v \omega$ $\sigma \kappa \varepsilon ı v$ seems to express, as Snell suggests, a kind of knowledge in which the subject

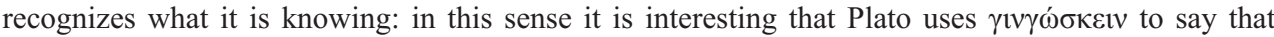
philosophers are able to know the truth about our bodily condition. See Snell, B.: Die Ausdrücke für den Begriff des Wissenschaft in der vorplatonischen Philosophie, Weidmannsche Buchhandlung,

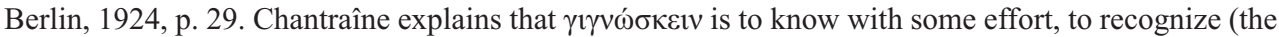
root $-\sigma \kappa \omega$ indicates to do something with effort). See Chantraine, P.: Dictionnaire etymologique de la langue grecque: histoire des mots, Klincksiek, Paris, 1968-1977, p. 224.
} 
selves. The interesting point is that Plato introduces in the Phaedo a new psychology and vision of man which places the problem of self-knowledge in the theoretical and practical field. To know oneself is only possible if we leave the opinions and appearances, and this is also a practical exercise, because the main obstacle in this process of recollection are bodily pleasures and pains. When the soul is intensely pleased or pained it considers ( $\dot{\eta} \gamma \varepsilon \tilde{\varepsilon} \sigma \theta \alpha 1,83 \mathrm{c}$ ) that those pleasures or pains are most clear ( $\dot{\varepsilon} v \alpha \rho \gamma \dot{\varepsilon} \sigma \tau \alpha \tau \sigma \nu)$ and most real ( $\dot{\alpha} \lambda \eta \theta \dot{\varepsilon} \sigma \tau \alpha \tau o v)$, so that it is through this affections that the soul lives in a deep ignorance. Pleasure and pain are some kind of sensible judgements that present something as desirable or avoidable and, in this sense, they can produce a false opinion ( $\left.\delta \delta^{\prime} \xi \alpha\right)$ about reality. The main way to come into reality is an exercise of introspection, leaving aside pleasures and pains, appetites and sensible impressions, in order to find something stable and real: it is a process

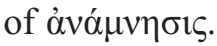

Avó $\mu v \eta \sigma ı \varsigma$ is an exercise of recollection and self-reflection in which the subject

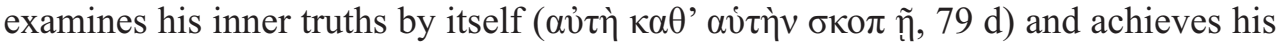
own reality: one realizes what is truly real and true, and in this sense one understands his position in the world. This exercise of recollection has been commonly understood as an intellectual activity based on the recognition of some inner truths we have in ourselves, but I would like to point out that it is not only a reflexive or theoretical task, but mainly practical. It is only possible to see with the eyes of the soul when one gets rid of the appearances 25 : Avó $\mu \eta \sigma r s$ goes hand in hand with $\kappa \alpha \theta \dot{\alpha} \rho \sigma \mathrm{s}$, and virtue is a way of self-purification of bad pleasures and desires, which are the main obstacle in order to see things properly 26 . In this sense it seems

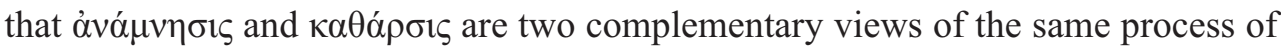
self-knowledge ${ }^{27}: \dot{\alpha} v \alpha \dot{\mu} \mu \eta \sigma \varsigma \varsigma$ is referred to the intellectual process of discovering our own inner truths, whereas $\kappa \alpha \theta \alpha$ á $\sigma 1 \varsigma$ is linked with a practical condition of the soul that allows intellectual clarification. Recollection is not possible without purification, and both steps begin with some kind of self-recognition in which the soul takes notice of its own situation.

On the other hand, the doctrine of $\dot{\alpha} v \alpha \dot{\mu} \mu \nu \eta \sigma \varsigma$ and $\kappa \alpha \theta \dot{\alpha} \rho \sigma 1 \varsigma$ on the Phaedo shows an interesting aspect of Plato's philosophy of man: self-knowledge is also self-freedom, understood as to be free from the appearances, to be able to recollect

\footnotetext{
25 See Festugière, A. J.: Contemplation et vie contemplative selon Platon, Vrin, Paris, 1950, p. 128.

26 See Frede, D.: Platons Phaidon, Wissenschaftliche Buchgesellschaft, Stuttgart, 2005, p. 21.

27 Dorter, for example, made a strong distintinction between recollection and purification. He explains that in the doctrine of recollection the human soul has the forms within itself, while in the doctrine of purification the soul strives to contemplate the forms. See Dorter, K.: "Equality, Recollection, and Purification", Phronesis 17 (1972), pp. 212-213. I think this strong distinction is made upon the supposition that Plato had different theories or doctrines in mind, what doesn't seem to be the case. In fact, Dorter concludes his essay (p. 218) saying that both doctrines may be compatible, different ways to approach the way the soul is related with the forms.
} 
over oneself. The real self is the rational soul, and his freedom comes when it is able to develop properly. In the Phaedo the problem of self-knowledge is placed in the tension between soul and body28: to be free from the appearances is to be free from the body. Although this tension will be different in other dialogues, he shows clearly that the self-knowledge process is also a process of inner freedom:

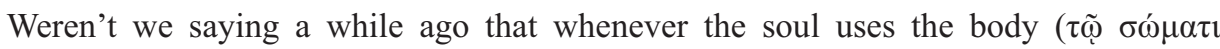
$\pi \rho о \sigma \varphi \chi \tilde{\eta} \tau \alpha 1)$ as a means to study anything, either by seeing or hearing or any other sense -because to use the body as a means is to study a thing through sense-perception ( $\tau$ ò $\delta \imath^{\prime} \alpha i \sigma \theta \eta \dot{\sigma \varepsilon \omega \varsigma} \sigma \kappa о \pi \varepsilon \tilde{\imath} v \tau \imath$ )- then it is dragged by the body towards objects that are never constant; and it wanders about itself, and is confused and dizzy, as if drunk, in virtue of contact with things of a similar kind? (Phaedo, $79 \mathrm{c}$ ).

It turns out, then, that the problem of the body towards self-knowledge is based on the instability of the objects of sense-perception, so that the soul is confused, unable to look the things through itself, but instead is only able to look through the

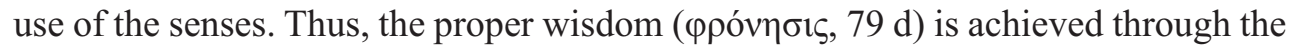
contact of the soul with the unvarying objects and this act of knowledge is also a process of self-knowledge 29 . In fact, Plato is able to say that perhaps this $\varphi \rho$ óv$\sigma \mathrm{r} \varsigma$

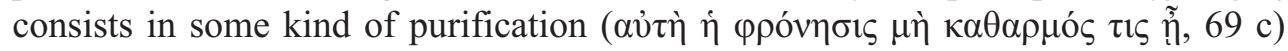
because there is not a clear distinction between practical and theoretical knowledge. Real wisdom is self-knowledge, which is the same as a right appreciation of what is more pure and truth in our lives: it is a practical and theoretical knowledge at the same time.

In the Phaedo Plato discovers an inner way of recollection in order to attain knowledge and virtue. This process of inner knowledge requires a practical and theoretical attitude of self-knowledge. The relationship between knowledge and virtue, as it was seen in the Charmides, has been deepened through the inner way of recollection, which is also a theoretical and practical task in life.

\section{Self-knowledge as contemplation of the inner ideas (beauty, justice, goodness) and transformation of reality: Republic}

It has been explained how Plato approached the question of self-knowledge in the Charmides and the Alcibiades I without concluding which kind of knowledge is

\footnotetext{
28 Plato's negative vision of the body in this dialogue must be understood taking into account the main question of the dialogue: does the soul continue living after death? See Frede, D.: Platons Phaidon, Wissenschaftliche Buchgesellschaft, Stuttgart, 1999, p. 19.

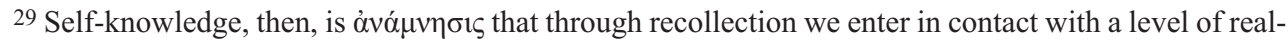
ity and knowledge which is more genuine to ourselves, previous to our life with the body. See Huber, C. E.: Anamnesis bei Plato, Max Hueber, München, 1964, pp. 362-364.
} 
present in virtue. Virtue, as a practical and epistemological disposition, seems to be the deepest kind of self-knowledge, but in the early dialogues he is not able to answer to the problem of ethical knowledge because he lacks a refined theory of knowledge and metaphysics. In the Phaedo, as it has been shown, he suggests an inner way of recollection as a mean towards truth and virtue, and here the main obstacle to self-knowledge is the body. The opposition between appearance and ideas changes lightly in Plato's Republic ${ }^{30}$. Here the conflict is not between body

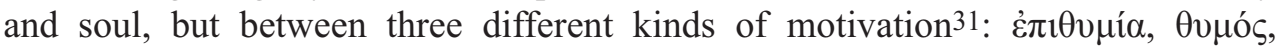
$\lambda$ ó ${ }_{0} \varsigma^{32}$, and the question of self-knowledge can be approached from his now developed metaphysics and theory of knowledge. For this question I would like to focus in one text of the VII book, where the Platonic $\pi \alpha 1 \delta \varepsilon i ́ \alpha$ is expressed as a process of personal raising:

The soul of every man does possess the power of learning the truth and the organ to see it with; and that, just as one might have to turn the whole body round in order that the eye should see light instead of darkness, so the entire soul must be turned away from this changing world, until its eye can bear to contemplate $(\theta \varepsilon \omega \mu \varepsilon \dot{v} \eta)$ reality and that supreme splendour which we have called the Good (Republic, $518 \mathrm{c})^{33}$.

The process of knowledge seems to be an awareness of what is most real, the Good, a principle that rules the whole reality and that is most pure, truth and beautiful. In this sense, to go out from the cave is to recollect over oneself. We know ourselves, we understand what is more real and true, when we are able to see things not with the eye of the body, but with the eye of the soul. It seems that Plato's theory of recollection of the Phaedo has been deepened and developed but here the tension doesn't come between the soul and the body. It is necessary, as it was in the Phaedo, a movement of conversion ( $\sigma \tau \rho \varepsilon \dot{\varphi} \varepsilon \imath v)$ of the soul, that should turn away

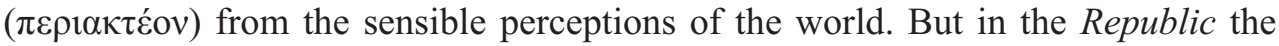

30 D. Sedley has recently pointed out some continuity between Plato's psychology and ethics of Phaedo and Republic. In both dialogues there is a purificatory virtue, real virtue, associated with the soul's liberation (Phaedo) or soul's gaze (Republic). See Sedley, D.: "Socratic Intellectualism in the Republic's Central Digression", The Platonic Art of Philosophy, G. Boys-Stones-D. El Murr-C. Gill (eds.), Cambridge University Press, Cambridge, 2013, pp. 84-85. His thesis is that Plato is always trying to continue and perfect Socrates' project. In this line of interpretation I suggest that the Delphic advice ( $\gamma v \tilde{\omega} \theta \imath \sigma \varepsilon \alpha \tau o ́ v)$, as a main topic in Socrates' activity, is one of the central features of Plato's philosophy.

31 See Cooper, J. M.: "Plato's Theory of Human Motivation", Reason and Emotion, Princeton University Press, Princeton, 1999, pp. 118-137.

32 "Conflict of motives - a conflict within the soul itself- is now fully recognized, and a psychology is outlined which to a large degree caters for it. No longer is the conflict between body and soul, as in the Phaedo; the conflict lies rather within the soul itself, as in the Gorgias". Robinson, T. M.: Plato's Psychology, University of Toronto Press, Toronto, 1995, p. 43.

33 For the Republic I use F. M. Cornford's translation (Oxford University Press, London, 1941). 
fight in the human soul is between knowledge and opinion, reality and appearances, reason and desire, and the process of understanding begins with a movement of conversion or self-understanding. This needs some detailed explanation.

Plato's tripartition of the soul gives a refined vision of man. Harmony and inner order is the key that allows the way to contemplation, because each part has its proper function, and it is only possible to contemplate the Good (which is harmony and proportion) when there is that inner proportion in the human soul. At the same time, the process of contemplation starts with some self-recognition in which the soul clarifies its own situation. Self-knowledge, understood as awareness of what is most real and true in ourselves (Alcibiades I), comes only when the rational part commands the appetitive and the passional parts, that is, when there is a practical and rational disposition towards the Good ${ }^{34}$. The Good is an object of contemplation, but it is also a rational and harmonious disposition ${ }^{35}$, and the deeper knowledge of the Good comes when we introduce it in our own lives. The good is that which every soul pursues and for its sake does all that it does $(505 \mathrm{~d})$. On the other hand, self-knowledge comes with the ruling of reason over the other parts of the soul, because reason knows what is best for the soul as a whole and for each of its parts (see Republic, $442 \mathrm{c}$ ). It has been a question of recent debate the way in which the three parts of the soul are related between them ${ }^{36}$. Some scholars understand these parts as different subjects of desire 37 , whereas others prefer to take them as different agencies of the same soul ${ }^{38}$. For the question of self-knowledge it must be said that the whole soul must pursue the good seeking the way of the rational part (Phaedrus $256 \mathrm{a}-\mathrm{b}$, Republic $586 \mathrm{e})^{39}$. It seems, then, that there is a psychological and metaphysical centre of volition above all kind of desires (and parts of the soul), the real "I" that should pursue the good with the help of the rational part. It would be interesting to examine the way in which this most real part of ourselves is related with the rational part of the soul, but this would be another matter of study.

\footnotetext{
34 In this sense Plato's philosophy does not represent a mystic position, although there can be some analogies with the mystical life. The aim of Plato's $\pi \alpha 1 \delta \varepsilon i$ is is not the mystic union with the ideas, as it may happen in Plotin's philosophy. See Friedländer, P.: Platon, vol. I, Walter de Gruyter, Berlin, 1964 [1928], pp. 76-89.

35 'L'ordre et l'harmonie du Gorgias, la mesure, la proportion parfaite du Philèbe, le Tout divin du Timée, des Lois, du Sophiste même, servent tour à tour, chez Platon, à définir ou figurer ce Bien, strictement indéfinissable". Diès, A.: Platon. La République. Introduction, Les Belles Lettres, Paris, 1970, p. 1xiii.

36 See Vallejo, A.: “The Theory of Conflict in Plato's Republic", Dialogues on Plato's Republic, N. Notomi-L. Brisson (eds.), Academia, Sankt Agustin, 2013, pp. 192-198.

37 See Bobonich, C.: Plato's Utopia Recast, Clarendon Press, Oxford, 2002, p. 219.

38 See Price A. W: Mental Conflict, Routledge, London and New York, 1995, p. 54.

39 It seems quite interesting C. Kahn's position, that points out that perhaps it would be better to speak of a general desire towards Good (Beauty, in case of the Symposium) that is over the rest of desires and motivational parts of the soul. See Kahn, C., "Plato's Theory of Desire", Review of Metaphysics 41 (1987), p. 101.
} 
It seems clear from the exposition of the VII Book of the Republic that the human being gets to know his own reality understanding the Good, but I would like to point out the practical dimension of this knowledge. To know oneself is primary to introduce order in the appetites, and this order enables the knowledge of deeper realities. But, on the other hand, this order begins with some self-clarification. As Plato states in the VII Book, the main problem of those who have no experience of

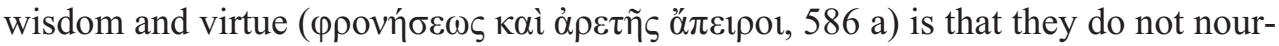

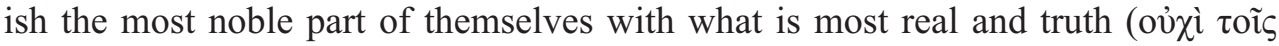

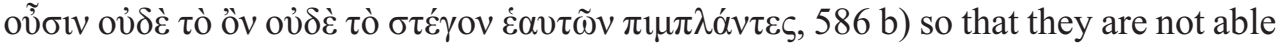
to appreciate the real value of sensible pleasures. Self-knowledge is then a process in which the soul knows better his position towards the Good in the way it understands it better and introduces some inner order. We need some inner order to appreciate the Good, and when we nourish the most noble part of ourselves, we are able to act better according to this knowledge.

In this sense, self-knowledge is a theoretical and practical task in life. Although Plato does not treat this idea explicitly there are passages in which he suggests it, as for example when he speaks of the qualities of the good judge:

To make a good judge, a man must be old. The knowledge of what wickedness is should have come late in life, not from a consciousness of its presence in his own soul (ov̉

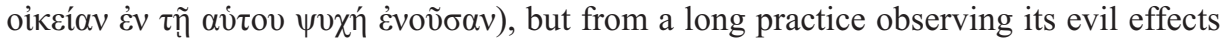
in the souls of others. It should be a matter of knowledge ( $\left.\dot{\varepsilon} \pi \_\tau \eta \dot{\mu \eta}\right)$, not of personal

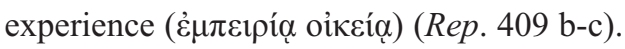

We are only able to know ourselves in the way we act justly, precisely because the bad personal experience enables us to see the real value of justice. This text points out an interesting idea of Plato's ethics of self-knowledge. Knowledge of good and evil doesn't consist in a theoretical knowledge, but rather is a practical knowledge, acquired through one's own disposition towards good and evil. The real knowledge of evil is only possible from a good ethical disposition, whereas the real knowledge of goodness is not possible from a bad disposition. Only a good man is able to know the real value of things because he has developed a rational soul up to a point that it is aware of what is really good for himself. We know ourselves in the way we introduce a practical order that enables us to appreciate and recognize what is more valuable for us.

The connection between the inner disposition of the soul and the level of knowledge one is able to achieve appears, then, as a central point in Plato's philosophy, and this connection is present in almost all the Platonic dialogues. The main problem of the soul is $\dot{\alpha} \mu \alpha \theta i \alpha$, that is, a practical attitude of ignorance and opinion in which one prefers to seek appetitive pleasures instead of the real good for the soul 40 .

40 See Sophist, 228 c-e. 
A $\mu \alpha \theta$ í $\alpha$ is not only a state of ignorance, but a foolish disposition towards what is really valuable, so that the $\alpha \mu \alpha \theta \eta \dot{s}$ doesn't want to exit from this state of ignorance 41 . The problem of self-knowledge, then, is a problem of self-disposition: it is only possible to look into the Good (that is, the principle that rules reality, what is most valuable and real to ourselves) in the way one is able to establish a rational order in the soul, so that the different appetites are commanded by reason. To know oneself is to contemplate Goodness and to introduce an inner order in the soul according to that goodness 42 . Self-knowledge is then a theoretical and practical task in life: the contemplation of the Good and the realization of this Good in our own lives ${ }^{43}$. Plato has found an epistemic ground for the knowledge of virtue (understood as self-knowledge), based on the contemplation of the Good; but, on the other hand, this contemplation is only possible in the way that the human being introduces order in his appetites and desires. Self-knowledge is a intellectual and practical process of self-clarification towards what is really valuable in life.

\section{Conclusions}

I have tried to show that the question of self-knowledge is an implicit central topic in Plato's philosophy, that, although is not clearly explained, it goes hand in hand with the development of his own psychology and metaphysics 44 . It must be noticed, however, that the concept of self-knowledge in Plato goes in connection with the Delphic advice: $\gamma v \tilde{\omega} \theta \mathrm{r} \sigma \varepsilon \alpha v \tau o ́ v$, that is, a practical knowledge of our own limitations. There is not in Plato's philosophy a concept of self-knowledge in the modern sense of the word, as "self-consciousness".

In Plato's Charmides self-knowledge seems to be an exercise of moderation and recognition of one's own limits. It is a practical and theoretical task in life, and the

\footnotetext{
41 See Rep. 535 c-d; Laws, 689 a.

42 "Für den Philosophen, der die Idee des Guten als die Spitze und den Enheitspunkt der gesammten Ideenwelt betrachtet, und der durch das Wissen des Guten das Wollen und Tun desselben als in unbedingter Notwendigkeit bestimmt erachtet, für Platon ist die Befähigung der menschliche Seele zu absoluter Erkenntnis zugleich ihre Bestimmung zu absoluter sittlicher Reinheit”. Bonitz, H.: Platonische Studien, Georg Olms, Hildesheim, 1968 [Berlin, 1886], p. 311.

43 In this sense it is interesting that in the Philebus the practical good is the introduction of order and harmony in the practical life. See Kahn, C.: "Plato on the Good", Was ist das für den Menschen Gute?, J. Szaif-M. Lutz (eds.), Walter de Gruyter, Berlin, 2004, p. 16.

44 It might be said, however, that with the development of his psychology and metaphysics Plato seems to be searching a better explanation of the main topics of Socrates' thought. I don't see a great discontinuity between Socrates' and Plato's psychology. A developmentalist approach can be found in Brickhouse, T. C., Smith, N.: Socratic Moral Psychology, University Press, Cambridge, 2010, pp. 193247. Against this developmentalist view see Rowe, C.: Plato and the Art of Philosophical Writing, University Press, Cambridge, 2007.
} 
problem in this dialogue is how to define this kind of wisdom. The analogy of virtue with the crafts and sciences makes difficult to explain the kind of knowledge present in virtue: it is not a practical knowledge as in the crafts, because it doesn't produce anything, and it is not a theoretical knowledge, because it doesn't have a clear object of study. Plato seems to be referring to an inner knowledge of good and evil, a "knowledge of knowledge", but he is not able to define it clearly. The same problem appears in Alcibiades I when Socrates and Alcibiades try to understand what is "to take care of oneself". Although they notice that the solution is in the soul, they are not able to define properly what the knowledge of virtue is.

Plato's contrast in the Phaedo between the appearances of the world and the reality of ideas places the question of self-knowledge in the purification ( $\kappa \theta \theta \dot{\alpha} \rho \sigma \iota \varsigma)$ and the exercise of recollection. To know oneself is to separate from the body in order to contemplate the inner ideas of beauty, goodness and truth. When we look into inside we find something more real and valuable as the appearances of the world. The real "I" is the rational soul that contemplates the inner truths in the exercise of recollection. Plato's doctrine of knowledge as recollection seems to be a solution not only for theoretical issues, but also for ethical knowledge. To the question "what kind of knowledge is present in virtue?" Plato could say that it is a knowledge of the pure ideas of justice, beauty and goodness the soul finds when it looks into itself. This knowledge, on the other hand, comes only in the way the soul

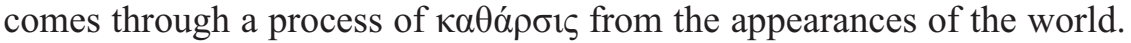

Plato's tripartition of the soul in the Republic shows that self-knowledge comes when the rational part controls and commands his appetitive desires and emotions. Self-knowledge is a process of education in which one is able to look into himself and see the Good, and then introduce a rational order into his own soul and in the city. Only the person that is able to introduce that order would be aware of his own position towards reality. Self-knowledge is above all a process of self-freedom and self-control.

Plato's philosophy can be understood as a development of the concept of бopía, wisdom, taken as a practical and theoretical attitude towards what is really valuable in life ${ }^{45}$. This $\sigma o \varphi i^{\prime} \alpha$ is a process of self-knowledge which appears in his first dialogues as a sort of $\tau \dot{\varepsilon} \chi v \eta$, it is then explained as an exercise of recollection and $\kappa \alpha \theta \alpha$ á $\sigma 1 \varsigma$, and it is developed in the Republic as a process of education in which the

45 'L'apparition de la figure du sage corresponde à une prise de conscience de plus en plus aiguë du moi, de la personnalité, de l'interiorité. Ce mouvement de prise de conscience est inauguré par la formule socratique: «Prends souci de toi-même», qui révèle à l'individu qu'il peut diriger sa vie, que son moi a une valeur propre, qui est aussi importante pour la Cité tout entière. [...] Le sage est précisément celui qui a su conquérir cette liberté intérieure, cette liberté de penser selon la norme de la Raison, de la Nature, qui peut s'opposer aussi bien aux opinions, aux prejuges, aux impératifs de la Cité qu'aux caprices du désir et de la passion". Hadot, P.: "La figure du sage", Études de philosophie ancienne, Les belles lettres, Paris, 1998, p. 247. 
learner must acquire an inner disposition towards the Good, ruling his soul according to his rational part. The oopós is the person who knows his own limits and is able to apprehend the Good and introduce a rational order in his life 46 . I have tried to point out that self-knowledge for Plato does not consist in a theoretic act of selfapprehension, but rather is a process of self-discovering in relation to the world and what is really valuable. In this sense, self-knowledge doesn't come in a direct act of self-comprehension, but rather as an indirect awareness of our own position towards what is most real: Good, Beauty and Truth.

But, on the other hand, self-knowledge is not only a question of contemplation, but also of practice. We know ourselves inasmuch as we introduce a practical order in our lives that gives place to contemplation. That is, as far as I can see, what we can learn about self-knowledge ( $\gamma v \tilde{\omega} \theta \imath$ $\sigma \varepsilon \alpha v \tau o ́ v)$ in the Platonic dialogues and one of the keys that allows us to understand his thought.

Manuel C. Ortiz de Landazuri

Universidad de Navarra

Departamento de Filosofía

mcruz@unav.es

\footnotetext{
46 In Plato's doctrine of Forms we found not only an epistemic or metaphysic theory, but also a solid foundation for his ethics in which theory and practice go hand in hand. See Kahn, C.: "The Motivation for Plato's Doctrine of Forms", Dialogues on Plato's Republic, N. Notomi-L. Brisson (eds.), Academia, Sankt Agustin, 2013, pp. 223-232.
} 